\title{
Performances and application of antisera produced by recombinant capsid proteins of Cymbidium mosaic virus and Odontoglossum ringspot virus
}

\author{
Shu-Chuan Lee $\cdot$ Ya-Chun Chang
}

Received: 29 September 2007 / Accepted: 18 February 2008 / Published online: 8 March 2008

(C) KNPV 2008

\begin{abstract}
Antisera against important orchid viruses, Cymbidium mosaic virus (CymMV) and Odontoglossum ringspot virus (ORSV), were separately produced using bacterially expressed recombinant capsid proteins (CP), instead of purified virus particles, as immunogens. These antisera were then designated as home-made CymMV CP antiserum (HM-Cy) and home-made ORSV CP antiserum (HM-OR). The high specificity of HM-Cy and HM-OR were confirmed by immunoblot. Their detection limits were determined using indirect-enzyme-linked immunosorbent assay (I-ELISA). Both HM-Cy and HM-OR showed low background reactivity to healthy plants and thus displayed a high $\mathrm{S} / \mathrm{H}$ ratio (sample OD405/healthy control OD405) in tested orchids. The data indicated that our antisera were efficient and accurate in determination of negative and positive results in ELISA test as commercial antibodies. Therefore, these homemade antisera of CymMV and ORSV are suitable for the certification programme of orchids due to their low cost and high specificity. HM-Cy and HM-OR were further used for a field survey to study the
\end{abstract}

S.-C. Lee $\cdot$ Y.-C. Chang $(\bowtie)$

Department of Plant Pathology and Microbiology,

National Taiwan University,

No. 1, Sec. 4, Roosevelt Road,

Taipei 10617, Taiwan

e-mail: ycchang@ntu.edu.tw incidence of CymMV and ORSV. The results showed that CymMV is more prevalent than ORSV in Taiwan.

Keywords Antibody.CymMV.Indirect-ELISA . ORSV

\section{Introduction}

The Orchidaceae is possibly the largest and most diverse plant family and contains important cultivated orchid species of Arachnis, Ascocentrum, Cattleya, Cymbidium, Dendrobium, Laelia, Oncidium, Paphiopedilum, Phalaenopsis, Renanthera, and Vanda and their hybrids (Zettler et al. 1990). Among many orchids grown in Taiwan, Phalaenopsis and Oncidium spp. are two major orchid genera cultivated by commercial growers and exported mainly to Japan, USA and Europe. There are more than 25 viruses reported to infect orchid plants (Zettler et al. 1990). Cymbidium mosaic virus (CymMV) and Odontoglossum ringspot virus (ORSV) are the most important viruses among them (Zettler et al. 1990; Wong et al. 1994; Ryu et al. 1995). Although symptoms induced by either virus can be severe, leaves produced by infected plants often look normal (Zettler et al. 1990). Therefore, virus diagnosis cannot rely on symptomatology alone. To solve the problem of reliable diagnosis for CymMV and ORSV in orchids, detec- 
tion methods based on targeting viral nucleic acids [such as reverse transcription-polymerase chain reaction (RT-PCR), hybridization and molecular beacon] (Lim et al. 1993; Ryu and Park 1995; Hu and Wong 1998; Seoh et al. 1998; Eun and Wong 2000; Eun et al. 2000; Lee and Chang 2006; Sherpa et al. 2006), viral capsid proteins (CP) [such as enzyme-linked immunosorbent assay (ELISA), quartz crystal microbalance (QCM) immunosensors, immuno-capillary zone electrophoresis (I-CZE), liquid chromatography/mass spectrometry (LC/MS) and matrix-assisted laser desorption-ionization (MALDI) mass spectrometry] (Arunasalam and Pearson 1989; Wong and Chng 1993; Eun and Wong 1999; Tan et al. 2000; Eun et al. 2002) or both [such as immunocapture-PCR (IC-PCR)] (Barry et al. 1996) were developed. Among these detection methods, ELISA is cost-effective and shows satisfying detection sensitivity (1-10 $\mathrm{ng} \mathrm{ml}^{-1}$; Hull 2002). It is particularly suitable for dealing with large amounts of samples in surveys or indexing. For a detection method depending on properties of viral proteins, preparation of an efficient antibody is important for its specificity and sensitivity. Viral CP is known to be responsible for the immune reaction against virus particles. The genetic variability of CymMV and ORSV CP genes has been investigated, and both showed high sequence conservation (Ajjikuttira et al. 2002). Therefore, the CPs of CymMV and ORSV provide good targets for antibody production and $\mathrm{CP}$-specific antisera should be able to detect these two important orchid viruses worldwide. Several kinds of antibodies prepared by the purified virions were used for a virus survey of orchid species. However, some orchid plants produced relatively high background reading values and thus healthy plants could not be distinguished from diseased plants (Elliott et al. 1996). This phenomenon may be due to the plant contaminants existing in purified virion preparations and therefore antibodies raised against virions react with the plant extracts in ELISA. Recently, a suitable alternative using recombinant CPs produced in bacterial cells instead of purified virions, was used to produce antiserum and proved to be very successful for detection purposes (Kim et al. 1998; Li et al. 1998; Cerovska et al. 2002; Hélias et al. 2003; Abou-Jawdah et al. 2004).

Accordingly, in this study, the strategy of antiserum production was to use Escherichia coliexpressed recombinant CPs of CymMV or ORSV as antigens. The performances of our antisera were compared with commercial antibodies by means of indirect-ELISA. A field survey of CymMV and ORSV was also conducted using our antisera. The results showed that these antisera produced by recombinant CPs of CymMV and ORSV were applicable for the routine tests of the orchid certification programme in Taiwan.

\section{Materials and methods}

Virus source and field sample collection

Phalaenopsis orchid plants infected by CymMV and ORSV were first identified with antibodies against CymMV and ORSV purchased from Agdia Inc. (Elkhart, IN, USA). Both viruses were isolated from the diseased orchids and then separately maintained in Nicotiana benthamiana. These plants were maintained in a greenhouse with day/night temperatures of $28 / 25^{\circ} \mathrm{C}$ and a time period of $16 / 8 \mathrm{~h}$ at National Taiwan University. Virus particles were purified from infected tissues of $N$. benthamiana according to the method of Lin and Chen (1991) for CymMV and Chapman (1998) for ORSV. For the field survey, the orchid plant samples of Phalaenopsis and Oncidium spp. were collected from six commercial farms located in the northern (Taipei, Yilan and Taoyuan Counties), central (Taichung County) and southern (Chiayi County) part of Taiwan.

\section{Extraction of plant total RNA}

Total RNA was extracted from leaf tissue of orchid plants with Plant Total RNA Extraction Miniprep System (Viogene, Sunnyvale, CA, USA) according to the protocol of the manufacturer. In brief, $0.1 \mathrm{~g}$ of leaf tissue was ground in liquid nitrogen with a pestle and mortar, and then the pulverized tissue powder was transferred to a microfuge tube. After mixed with $450 \mu \mathrm{l}$ of RX Buffer, the lysate was filtered using a Shearing Tube. The clear lysate was mixed with $230 \mu \mathrm{l}$ of absolute ethanol, and then filtered using a Plant Total RNA Mini Column. This column was then washed once with WF Buffer and twice with WS Buffer. Finally, plant total RNA was eluted with $50 \mu \mathrm{l}$ of RNase-free $\mathrm{ddH}_{2} \mathrm{O}$ and could then be used directly for RT-PCR or stored at $-80^{\circ} \mathrm{C}$ for future use. 


\section{RT-PCR}

For $12.5 \mu \mathrm{l}$ RT reaction, $3.5 \mu \mathrm{l}$ of extracted plant total RNA (350 ng) was mixed with $0.5 \mu \mathrm{l}$ of $5 \mu \mathrm{M}$ reverse primer and $1 \mu \mathrm{l}$ of $\mathrm{ddH}_{2} \mathrm{O}$. The solution was heated for $10 \mathrm{~min}$ at $70^{\circ} \mathrm{C}$, instantly cooled down on ice for $5 \mathrm{~min}$ and then an RT mixture including $3.25 \mu \mathrm{l}$ $\mathrm{ddH}_{2} \mathrm{O}, 2.5 \mu \mathrm{l} 5 \times$ first strand buffer (Promega, Madison, WI, USA), $1.25 \mu \mathrm{l}$ dNTPs $(10 \mathrm{mM})$, $0.25 \mu \mathrm{rRNasin}\left(40 \mathrm{U} \mu \mathrm{l}^{-1}\right.$, Promega) and $0.25 \mu \mathrm{l}$


added and incubated at $42^{\circ} \mathrm{C}$ for $60 \mathrm{~min}$. For PCR, a $50 \mu \mathrm{l}$ reaction containing $2 \mu \mathrm{l}$ RT product, $5 \mu 110 \times$ ThermoPol reaction buffer (New England BioLabs Inc., Beverly, MA, USA), $5 \mu$ forward and reverse primers $(5 \mu \mathrm{M}$ each), $5 \mu \mathrm{l}$ dNTPs $(2 \mathrm{mM}), 1 \mu \mathrm{l}$

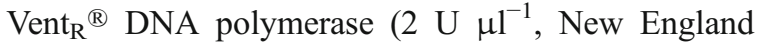

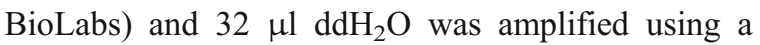
GeneAmp ${ }^{\circledR}$ PCR system 2400 (Perkin-Elmer Applied Biosystems, Foster City, CA, USA) with a $5 \mathrm{~min}$ denaturation step at $96^{\circ} \mathrm{C}$, followed by 30 cycles of $96^{\circ} \mathrm{C}$ for $30 \mathrm{~s}, 52^{\circ} \mathrm{C}$ for $30 \mathrm{~s}, 72^{\circ} \mathrm{C}$ for $30 \mathrm{~s}$, and a final extension step at $72^{\circ} \mathrm{C}$ for $7 \mathrm{~min}$. RT-PCR products were then analyzed by $1 \%$ agarose gel electrophoresis.

Construction and expression of the recombinant $C y m M V$ and $O R S V C P$ genes

For amplification and cloning of CymMV CP, sequence data of CymMV (AF016914, AY571289 and U62963) were collected from the GenBank of the National Centre for Biotechnology Information. Nucleotide sequences were aligned using the PILEUP and PRETTY programmes in GCG Version 11.1 (Accelrys Inc., San Diego, CA, USA). Based on the results of sequence alignment, a forward primer CyCP-F1: 5'ATGGGAGAGYCCACTCCARCYCCAGC-3' (three degenerate nucleotides were designed to ensure the amplification of different isolates of CymMV, $\mathrm{Y}=\mathrm{C}$ and $\mathrm{T} ; \mathrm{R}=\mathrm{A}$ and $\mathrm{G}$ ) and a reverse primer $\mathrm{CyCP}-\mathrm{R} 1: 5^{\prime}$ ATCGCTCGAGTTCAGTAGGGGGTGCAGGCA-3' (bold type indicated a created $X h o I$ site and the italic type represented the clamp sequences) were designed to amplify the $C P$ gene of CymMV. After RT-PCR, the expected 679-bp fragment of CymMV CP was digested with $X h o \mathrm{I}$ and gel eluted by GFX ${ }^{\mathrm{TM}}$ PCR DNA and Gel Band Purification Kit (GE Healthcare, Buckinghamshire, UK). The purified fragment was then ligated to expression vector, pET29a $(+)$ (Novagen, Madison, WI, USA), which had been digested with EcoRV and XhoI. The ligation products were transformed to $E$. coli $\mathrm{DH} 5 \alpha$. The transformants were first screened with enzyme digestion and selected clones were further confirmed by sequencing. Correct clones were used to transform to E. coli BL21 (DE3) and express the recombinant $\mathrm{CP}$ of CymMV which contained the entire viral CP with 30 amino acids of vector fused to its $\mathrm{N}$ terminus and a His-tag fused to its $\mathrm{C}$ terminus. Half milliliter of bacterial suspension was collected each hour after $1 \mathrm{mM}$ isopropyl- $\beta$-Dthiogalactopyranoside (IPTG) induction. The supernatant was discarded after centrifugation at 5,000 rpm for $10 \mathrm{~min}$, the pellets were resuspended in $50 \mu \mathrm{l}$ of SDS sampling buffer and $15 \mu \mathrm{l}$ was analyzed by $12 \%$ sodium dodecyl sulfate polyacrylamide gel electrophoresis (SDS-PAGE; Sambrook and Russell 2001). The recombinant CP was purified using Ni-NTA agarose (QIAGEN, Valencia, CA, USA) following the manufacturer's manual. The construction and expression of ORSV CP were similar to CymMV described above. Based on the alignment result of ORSV sequence data (NC_001728, AY571290, S83257 and U34586), specific primers for ORSV CP gene including a forward primer ORCP-F1: 5'-ATGTCTTACAC TATTACAGACCCG-3' and a reverse primer ORCPR 1: 5'-ATGCCTCGAGGGAAGAGGTCCAAG TAAGTCC-3' (bold type represented the created XhoI site and the italic type indicated the clamp sequences) were designed. The expected amplified fragment of ORSV CP is $484 \mathrm{bp}$.

\section{I-ELISA}

Indirect-ELISA was performed according to the protocol of Agdia Inc. with some modification. One hundred $\mathrm{mg}$ of plant tissue was ground in $1 \mathrm{ml}$ of indirect sample extraction buffer (ISE buffer, $15 \mathrm{mM}$ $\mathrm{Na}_{2} \mathrm{CO}_{3}, 35 \mathrm{mM} \mathrm{NaHCO}, 2 \%$ polyvinylpyrrolidone (MW 40,000), pH 9.6). One hundred microliter of the extracts were coated to the 96-well ELISA plate (NUNCTM, Denmark) and incubated at $37^{\circ} \mathrm{C}$ for $1 \mathrm{~h}$. Each sample had duplicated wells. After six to eight washings with phosphate-buffered saline + Tween-20 (PBST; $137 \mathrm{mM} \mathrm{NaCl}, 8 \mathrm{mM} \mathrm{Na} \mathrm{HPO}_{4}, 1.5 \mathrm{mM}$ $\mathrm{KH}_{2} \mathrm{PO}_{4}, 2.7 \mathrm{mM} \mathrm{KCl}, 0.05 \%$ Tween-20, $\mathrm{pH} 7.4$ ), the ELISA plate was then blocked with $1 \%$ skim milk solution diluted in coating buffer $\left(15 \mathrm{mM} \mathrm{Na} \mathrm{CO}_{3}\right.$, 
$35 \mathrm{mM} \mathrm{NaHCO}_{3}, \mathrm{pH} 9.6$ ) at $37^{\circ} \mathrm{C}$ for $1 \mathrm{~h}$. After six to eight washings with PBST buffer, $100 \mu \mathrm{l}$ of CymMV or ORSV antibodies diluted in ECI buffer $(0.2 \%$ bovine serum albumin, 2\% polyvinylpyrrolidone in PBST buffer, $\mathrm{pH}$ 7.4) was added to the ELISA plates and incubated at $37^{\circ} \mathrm{C}$ for $1.5 \mathrm{~h}$. The antibodies purchased from Agdia Inc. were diluted 200-fold and antisera produced in this study were diluted 10,000fold. After six to eight washings with PBST buffer, $100 \mu \mathrm{l}$ of 10,000 -fold diluted alkaline phosphatase (AP)-conjugated goat anti-rabbit secondary antibody (QED Bioscience Inc. San Diego, CA, USA) was added and incubated at $37^{\circ} \mathrm{C}$ for $1 \mathrm{~h}$. Finally $100 \mu \mathrm{l}$ of $p$-nitrophenylphosphate (PNP) solution (1 $\mathrm{mg} \mathrm{ml} \mathrm{m}^{-1}$ ), dissolved in PNP buffer $(9.7 \%$ diethanolamine, $0.5 \mathrm{mM} \mathrm{MgCl}_{2}, \mathrm{pH} 9.8$ ), was added after six to eight washings with PBST buffer. The values of $\mathrm{OD}_{405}$ of each sample were measured by the Spectra MAX 340 (Molecular Devices Co., Berkeley, CA, USA) after $60 \mathrm{~min}$ incubation. A sample was considered positive if the absorbance value was greater than twice the mean value of the healthy controls.

Immunoblot analysis

Crude plant extracts were prepared by grinding plant tissues in 20 volumes of $0.01 \mathrm{M}$ sodium phosphate buffer ( $\mathrm{pH}$ 7.2). After centrifugation at $12,000 \mathrm{rpm}$ for $5 \mathrm{~min}$, the supernatants were collected and used for immunoblot assay. CymMV and ORSV virions purified from infected $N$. benthamiana plants were used as viral CP controls. The total proteins of plant tissue were quantified with Bio-Rad Protein Assay Kit (Bio-Rad, Hercules, CA, USA) and $0.3 \mu \mathrm{g}$ of total proteins were separated by $12 \%$ SDS-PAGE in triplicate. One of the three gels was stained with Coomassie brilliant blue and the other two were transferred to polyvinylidene fluoride (PVDF) membranes (Osmonics, Westborough, MA, USA). After blocking with $0.3 \%$ non-fat milk solution, one membrane was reacted with anti-CymMV CP antiserum (HM-Cy) and the other with anti-ORSV CP antiserum (HM-OR). Membranes were incubated in $0.3 \%$ non-fat milk, $0.2 \%$ chicken albumin and PBST buffer containing applicable antiserum diluted 1:10,000 at room temperature for $1 \mathrm{~h}$, respectively. After that, the membranes were probed with AP-conjugated goat anti-rabbit secondary antibody and then reacted with the colorimetric substrate, NBT/BCIP (Roche Applied Science, Mannheim, Germany).

\section{Results}

Expression of recombinant CymMV and ORSV CPs for antiserum production

A 679-bp DNA fragment corresponding to $C y m M V$ $C P$ gene and a 484-bp DNA fragment of ORSV CP gene were amplified from total RNA of infected orchid plants with designed specific primer pairs, CyCP-F1/CyCP-R1 and ORCP-F1/ORCP-R1, respectively (Fig. 1). The fragments were cloned into expression vector, pET29a(+), to generate pET29a $(+)-\mathrm{CyCP}$ and pET29a(+)-ORCP after applicable restriction enzyme digestion. One correct and sequenced clone of each virus was selected for recombinant protein expression. Because there are 30 and eight amino acids derived from the vector fused to the $\mathrm{N}$ and $\mathrm{C}$ termini of expressed protein, recombinant viral CPs should have higher molecular weights than wild type CPs. The predicted $28-\mathrm{kDa}$ recombinant CymMV $\mathrm{CP}$ and $22-\mathrm{kDa}$ recombinant ORSV CP were successfully expressed in E. coli BL21 (DE3) after $1 \mathrm{~h}$ induction by IPTG and gradually increased for another $2 \mathrm{~h}$ (Fig. 2). A large amount of expressed recombinant $\mathrm{CP}$ was purified

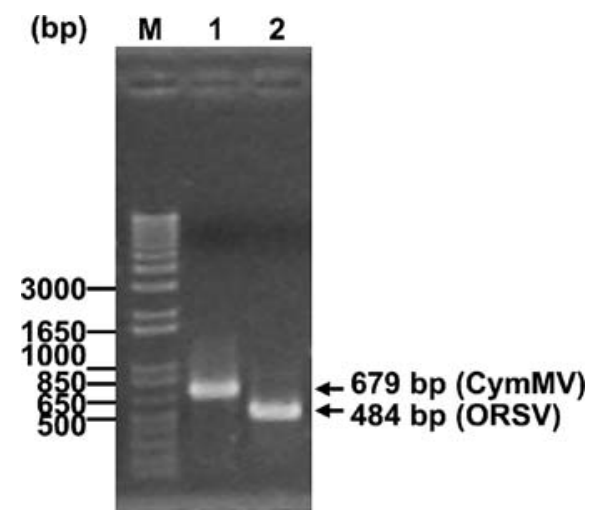

Fig. 1 Amplification of $C y m M V$ and $O R S V C P$ genes from total RNA of diseased orchid by RT-PCR. Lane 1: a 679-bp DNA fragment of CymMV CP gene amplified by CyCP-F1 and CyCP-R1 primers; lane 2: a 484-bp DNA fragment of ORSV $C P$ gene amplified by ORCP-F1 and ORCP-R1 primers; lane $M$ : $1 \mathrm{~kb}$ Plus DNA Ladder (Invitrogen, Carlsbad, CA, USA). The positions of CymMV and ORSV CP genes are indicated by arrows 
a

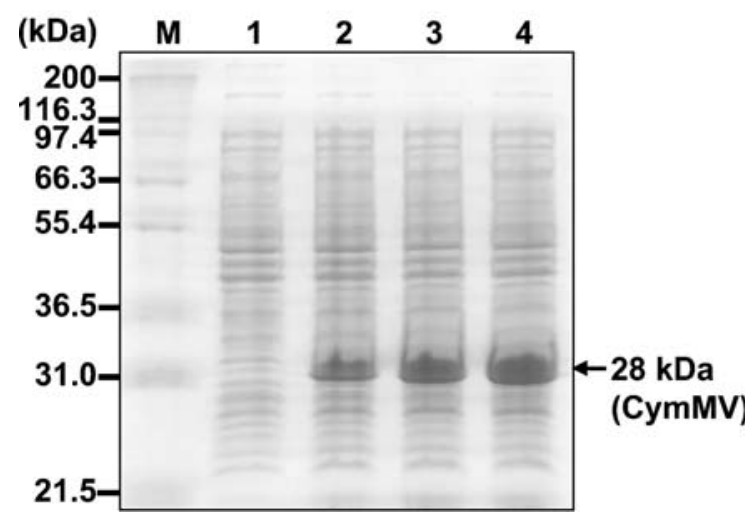

Fig. 2 Bacterial lysates of E. coli BL21 (DE3) transformed with pET29a(+)-CyCP (a) and pET29a(+)-ORCP (b) were analyzed in a $12 \%$ SDS-polyacrylamide gel. Lane 1 , no IPTG induction; lane 2, $1 \mathrm{~h}$ after IPTG induction; lane 3, $2 \mathrm{~h}$ after IPTG induction; lane $4,3 \mathrm{~h}$ after IPTG induction. Lane $M$,

using Ni-NTA agarose. The antisera of CymMV and ORSV were separately prepared from the purified recombinant CPs by a local private company. These antisera were thus designated as home-made CymMV $\mathrm{CP}$ antiserum (HM-Cy) and home-made ORSV CP antiserum (HM-OR).

Specificity of HM-Cy and HM-OR analyzed by immunoblot

To test the specificity of HM-Cy and HM-OR, total proteins of healthy and diseased orchid plants infected by CymMV, ORSV or both were assayed by immunoblot analysis. Purified viral particles of CymMV and ORSV were used as CP size controls. Equal amount of plant total proteins were separated in SDSPAGE and confirmed by Coomassie brilliant blue staining (Fig. 3a). According to the immuno-detection result, HM-Cy reacted with the $\mathrm{CP}$ subunits of CymMV virion as well as CymMV CP in the crude extracts derived from CymMV- and mix-infected orchid plants. Apparently it did not react with any proteins of healthy orchids or ORSV proteins in ORSV- and mix-infected orchid plants (Fig. 3b). A similar result was observed with HM-OR. HM-OR detected CPs of ORSV virion and also reacted with the CP of ORSV in the crude extracts from ORSVand mix-infected orchid plants. HM-OR obviously reacted neither with any proteins of healthy orchids nor CymMV proteins in CymMV- and mix-infected b

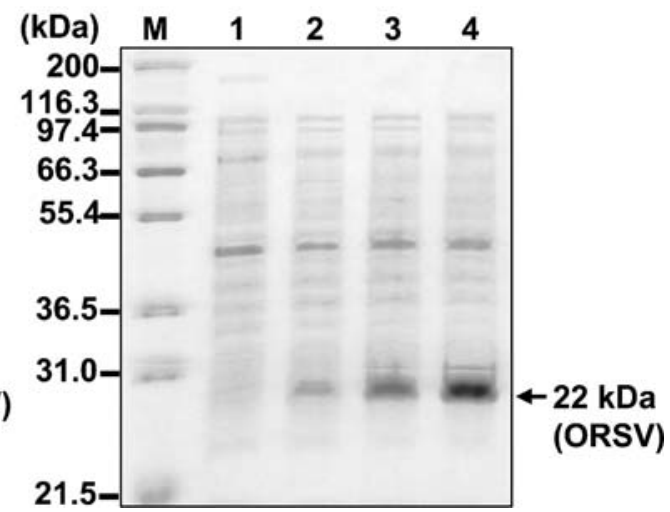

Mark12 ${ }^{\mathrm{TM}}$ Unstained Standard (Invitrogen, Carlsbad, CA, USA) with marker molecular weights indicated. The positions of the expressed recombinant proteins are indicated by arrows and the numbers represent the deduced molecular weights

plants (Fig. 3c). Some smaller proteins reacting to CymMV or ORSV antisera might be degraded products of the virus CP. According to these results, HM-Cy and HM-OR are highly specific and can be used for detection and diagnosis of orchid plants.

\section{Detection sensitivity of HM-Cy and HM-OR}

Since high specificity of HM-Cy and HM-OR were proved by immunoblot, the detection limits of both antisera were then determined using I-ELISA. The commercial antibodies against CymMV and ORSV purchased from Agdia Inc. (named as A-Cy and AOR) were used as detection controls. I-ELISA was performed using orchid plants infected by either CymMV or ORSV. A series of diseased samples was prepared by diluting with healthy plant extracts in fivefold intervals and used to verify the sensitivity of home-made antisera. A reaction was considered positive if the ELISA absorbance value was greater than twice the mean of the healthy controls. In other words, a reaction was judged positive when its $\mathrm{S} / \mathrm{H}$ ratio (sample $\mathrm{OD}_{405}$ /healthy control $\mathrm{OD}_{405}$ ) was $>2$. Both HM-Cy and A-Cy revealed low absorbance values with healthy plants in I-ELISA. With diseased samples, the detection limit of HM-Cy was in 25-fold $\left(5^{2}\right)$ dilution and showed no difference to A-Cy. However, HM-Cy exhibited higher $\mathrm{S} / \mathrm{H}$ ratios than A$\mathrm{Cy}$ in the same set of samples (Fig. 4a). When extending the incubation time to $120 \mathrm{~min}$, the $\mathrm{S} / \mathrm{H}$ 


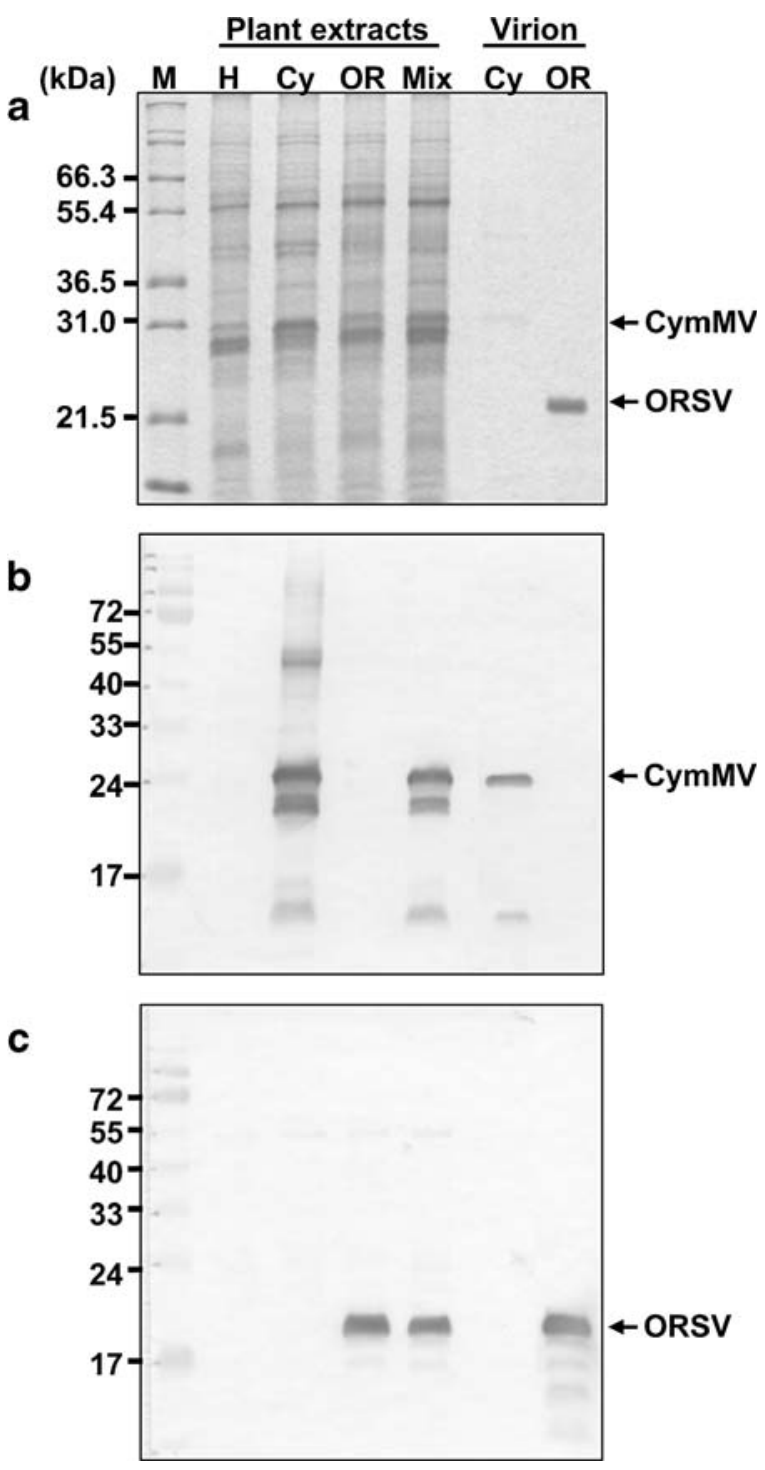

Fig. 3 Specificity of home-made CymMV and ORSV antisera (HM-Cy and HM-OR) analyzed by immunoblot. Crude extracts of healthy and diseased orchid plants, and purified viral particles were separated by $12 \%$ SDS-PAGE. The gel was stained with Coomassie brilliant blue (a) or transferred to a PVDF membrane which then reacted with anti-CymMV antiserum (b) or anti-ORSV antiserum (c). Four types of plant extracts were prepared from healthy (lane $H$ ), CymMV-infected (lane $C y$ ), ORSV-infected (lane $O$ ) and mix-infected (lane Mix) orchid plants. Lanes virion $C y$ and $O R$ represent virus particles purified from infected Nicotinana benthamiana and were used as viral $\mathrm{CP}$ size controls. Lane $M$, Mark12 ${ }^{\mathrm{TM}}$ Unstained Standard (Invitrogen, Carlsbad, CA, USA) in (a), and PageRuler $^{\mathrm{TM}}$ Prestained Protein Ladder (Fermentas, Hanover, MD, USA) in (b) and (c). Molecular weights of the markers are indicated on the left. The positions of CymMV and ORSV CPs are indicated by arrows ratios of 125 -fold $\left(5^{3}\right)$ diluted samples probed by HM$\mathrm{Cy}$ and A-Cy increased to 2.20 and 1.40, respectively. The former was thus considered as a positive reaction (Fig. 4a). This result indicated that HM-Cy possessed detection sensitivity reacting to 125 -fold dilution of CymMV-infected tissues in the I-ELISA test. Unlike HM-Cy, the ELISA absorbance values of HM-OR were lower than those of A-OR in all tested samples

\section{a}

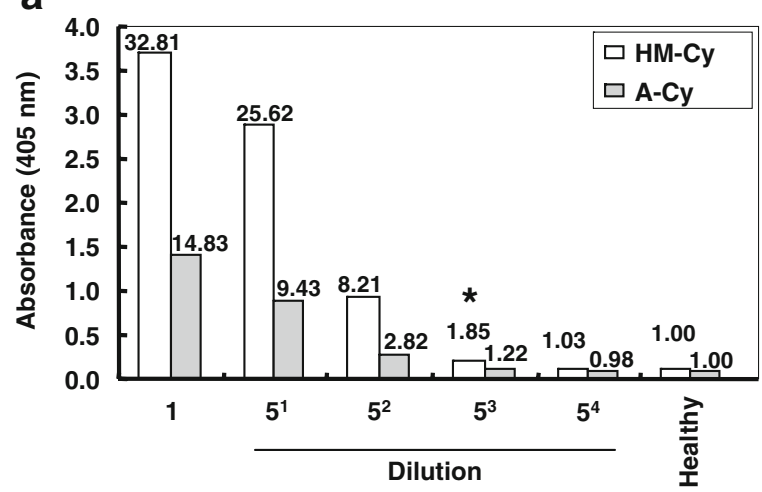

b

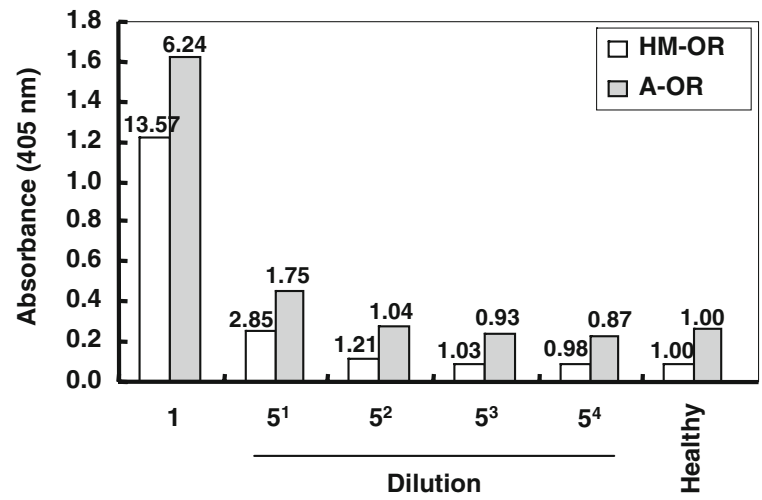

Fig. 4 Detection sensitivities of home-made and commercial antibodies against CymMV and ORSV. I-ELISA was performed to compare the detection limit of antibodies against CymMV (a, white column: HM-Cy; grey column: A-Cy) and ORSV (b, white column: HM-OR; grey column: A-OR). Original diseased orchid extract prepared by ISE buffer was considered as 1 and a fivefold serial dilutions $\left(5^{1}\right.$ to $5^{4}$ fold) of diseased samples were prepared with healthy plant extracts. The values of $\mathrm{OD}_{405}$ of each sample were measured after 60 min incubation. The absorbance value of each reaction was plotted. Number above the column represents the $\mathrm{S} / \mathrm{H}$ ratio (sample $\mathrm{OD}_{405}$ /healthy control $\mathrm{OD}_{405}$ ) of each reaction in each antibody. A reaction was considered positive when the $\mathrm{S} / \mathrm{H}$ ratio was $>2$. *: the $\mathrm{S} / \mathrm{H}$ ratio of this sample probed by HY-Cy reached 2.20 when incubation time was extended to $120 \mathrm{~min}$ and was then considered as a positive reaction. In contrast to $\mathrm{A}-\mathrm{Cy}$, the $\mathrm{S} / \mathrm{H}$ ratio of the same diluted sample was 1.40 when incubation time was extended to $120 \mathrm{~min}$ and was still considered as a negative reaction 
(Fig. 4b). However, the relative detection sensitivity of HM-OR reached to fivefold dilution of diseased samples according to the $\mathrm{S} / \mathrm{H}$ ratio but $\mathrm{A}-\mathrm{OR}$ was only able to detect the original undiluted diseased sample, even if the incubation time was $60 \mathrm{~min}$ (Fig. 4b) or $120 \mathrm{~min}$ (data not shown). This result might be partially due to the relative high absorbance value of A-OR in healthy samples compared with HM-OR (Fig. 4b).

Sixteen Phalaenopsis orchid samples and one healthy orchid plant were used for the I-ELISA test with antibodies described above. In tests against CymMV CP, HM-Cy displayed higher absorbance values and higher $\mathrm{S} / \mathrm{H}$ ratios than those of $\mathrm{A}-\mathrm{Cy}$, and both antibodies produced low absorbance values to the healthy control (Table 1). As to anti-ORSV CP antibodies, although HM-OR had lower absorbance values than A-OR, the numbers of positive reactions judged by the $\mathrm{S} / \mathrm{H}$ ratio were the same (Table 1 ). This was the consequence of different absorbance values of HM-OR and A-OR in healthy samples in which the HM-OR gave much lower $\mathrm{OD}_{405}$ than $\mathrm{A}-\mathrm{OR}$ as observed previously (Fig. 4b; Table 1). From the above ELISA results, both of the antisera produced by E. coli-expressed recombinant CPs of CymMV and ORSV revealed reliable specificity and sensitivity as commercial antibodies.
Field survey for the incidence of CymMV and ORSV in Taiwan

HM-Cy and HM-OR were further used to investigate the incidence of CymMV and ORSV in Taiwan. For the field survey, the orchid plant samples were collected from six commercial farms located in five different counties. A total of 150 samples including 94 Phalaenopsis samples and 56 Oncidium samples were collected. The detection results indicated $28 \%$ of the collected samples were positive for virus infection including 21.3\% for CymMV alone, $1.3 \%$ for ORSV alone and $5.3 \%$ for mixed infection (Table 2). The incidence of CymMV in single and mixed infections ranged from 3.3 to $63 \%$ in different commercial farms. The commercial farm VI in Chiayi County which routinely performed detection with ELISA using commercial antiserum showed the lowest incidence of CymMV infection (3.3\%) among six tested farms. Whereas the commercial farm $\mathrm{V}$ in the same county which did not perform any indexing within the production process revealed the highest occurrence $(63 \%)$ of CymMV, including $51.9 \%$ of single infection and $11.1 \%$ of mixed infection. The incidence of ORSV in different commercial farms ranged from $0 \%$ to $18.5 \%$ covering single and mixed infections (Table 2). According to our survey results,

Table 1 Indirect-ELISA test of the home-made CymMV and ORSV antisera (HM-Cy and HM-OR) produced by E. coli-expressed recombinant capsid proteins and antibodies purchased from Agdia Inc. (A-Cy and A-OR)

\begin{tabular}{|c|c|c|c|c|c|c|c|c|c|}
\hline \multirow[t]{3}{*}{ Sample number } & \multicolumn{4}{|c|}{ Antibody } & \multirow[t]{3}{*}{ Sample number } & \multicolumn{4}{|c|}{ Antibody } \\
\hline & \multicolumn{2}{|c|}{ HM-Cy } & \multicolumn{2}{|l|}{$\mathrm{A}-\mathrm{Cy}$} & & \multicolumn{2}{|c|}{ HM-OR } & \multicolumn{2}{|l|}{ A-OR } \\
\hline & $\mathrm{OD}_{405}$ & $\mathrm{~S} / \mathrm{H}^{\mathrm{a}}$ & $\mathrm{OD}_{405}$ & $\mathrm{~S} / \mathrm{H}^{\mathrm{a}}$ & & $\mathrm{OD}_{405}$ & $\mathrm{~S} / \mathrm{H}^{\mathrm{a}}$ & $\mathrm{OD}_{405}$ & $\mathrm{~S} / \mathrm{H}^{\mathrm{a}}$ \\
\hline $\mathrm{C}-1$ & 2.871 & 27.34 & 1.054 & 13.51 & $\mathrm{O}-3$ & 0.088 & 1.01 & 0.219 & 1.16 \\
\hline $\mathrm{C}-2$ & 3.532 & 33.64 & 1.796 & 23.03 & $\mathrm{O}-7$ & 0.090 & 1.03 & 0.240 & 1.28 \\
\hline $\mathrm{C}-3$ & 3.268 & 31.12 & 1.258 & 16.13 & $\mathrm{O}-14$ & 0.470 & 5.40 & 0.908 & 4.83 \\
\hline $\mathrm{C}-4$ & 3.144 & 29.94 & 1.135 & 14.55 & O-16 & 0.367 & 4.22 & 0.738 & 3.93 \\
\hline $\mathrm{C}-5$ & 2.754 & 26.23 & 1.074 & 13.77 & $\mathrm{O}-17$ & 0.464 & 5.33 & 0.953 & 5.07 \\
\hline $\mathrm{C}-6$ & 2.924 & 27.85 & 0.825 & 10.58 & O-18 & 0.495 & 5.69 & 0.851 & 4.53 \\
\hline $\mathrm{C}-7$ & 1.875 & 17.86 & 0.510 & 6.54 & O-19 & 0.310 & 3.56 & 0.587 & 3.12 \\
\hline $\mathrm{C}-8$ & 3.125 & 29.76 & 1.011 & 12.96 & $\mathrm{O}-20^{\mathrm{b}}$ & 0.166 & 1.91 & 0.361 & 1.92 \\
\hline Healthy & 0.105 & 1.00 & 0.078 & 1.00 & Healthy & 0.087 & 1.00 & 0.188 & 1.00 \\
\hline
\end{tabular}

${ }^{\mathrm{a}} \mathrm{S} / \mathrm{H}$ ratio represents the absorbance value ratio of sample/healthy plant (sample $\mathrm{OD}_{405} /$ healthy control $\left.\mathrm{OD}_{405}\right)$ measured after 60 min incubation. A reaction was considered positive when the $\mathrm{S} / \mathrm{H}$ ratio was $>2$

${ }^{\mathrm{b}}$ The S/H ratio of $\mathrm{O}-20$ reached 2.36 and 2.12 with HM-OR and A-OR, respectively, after 120 min incubation and were both considered as positive reactions 
Table 2 Number of samples (\% in parenthesis) of orchid plants collected from different farms testing positive for CymMV and ORSV by I-ELISA using HM-Cy and HM-OR antisera simultaneously

\begin{tabular}{|c|c|c|c|c|c|c|}
\hline Farm $^{\mathrm{a}}$ & Orchid & Number of samples & CymMV single infection & ORSV single infection & Mixed infection & Subtotal \\
\hline \multicolumn{7}{|c|}{ Northern Taiwan } \\
\hline \multirow[t]{2}{*}{ I } & Phalaenopsis & 10 & $4 / 10(40)$ & $0 / 10(0)$ & $1 / 10(10)$ & $5 / 10(50)$ \\
\hline & Oncidium & 6 & $1 / 6(16.7)$ & $0 / 6(0)$ & $1 / 6(16.7)$ & $2 / 6(33.3)$ \\
\hline II & Phalaenopsis & 27 & 4/27 (14.8) & $2 / 27(7.4)$ & $3 / 27(11.1)$ & $9 / 27(33.3)$ \\
\hline III & Oncidium & 22 & $6 / 22(27.3)$ & $0 / 22(0)$ & $0 / 22(0)$ & $6 / 22(27.3)$ \\
\hline \multicolumn{7}{|c|}{ Central Taiwan } \\
\hline IV & Oncidium & 28 & $2 / 28(7.1)$ & $0 / 28(0)$ & $0 / 28(0)$ & $2 / 28(7.1)$ \\
\hline \multicolumn{7}{|c|}{ Southern Taiwan } \\
\hline $\mathrm{V}$ & Phalaenopsis & 27 & $14 / 27(51.9)$ & $0 / 27(0)$ & 3/27 (11.1) & $17 / 27(63)$ \\
\hline $\mathrm{VI}^{\mathrm{b}}$ & Phalaenopsis & 30 & $1 / 30(3.3)$ & $0 / 30(0)$ & $0 / 30(0)$ & $1 / 30(3.3)$ \\
\hline \multicolumn{2}{|c|}{ Total infected } & 150 & $32 / 150(21.3)$ & $2 / 150(1.3)$ & $8 / 150(5.3)$ & $42 / 150(28)$ \\
\hline
\end{tabular}

${ }^{a}$ The orchid samples were collected from six commercial farms located in different areas including Taipei (farm I), Yilan (farm II), Taoyuan (farm III), Taichung (farm IV) and Chiayi (farms V and VI) Counties

${ }^{\mathrm{b}}$ The orchid plants grown in farm VI were routinely tested with ELISA using commercial antibodies

Oncidium plants were not infected by ORSV alone. Although Phalaenopsis orchids in farms I, II and V had infection rates of ORSV $>10 \%$, the same orchid species in farm VI with routine detection exhibited no infection of ORSV. In conclusion, the infection incidence of CymMV was much higher than ORSV in Taiwan and most of ORSV infection (80\%) was mix-infected with CymMV.

\section{Discussion}

Orchids especially Oncidium and Phalaenopsis spp. are important ornamental plants cultivated in Taiwan. CymMV and ORSV are two economically important and covalent pathogens in the orchid industry and are distributed worldwide (Zettler et al. 1990). In 2002, the rules and regulations for the certification of Oncidium hybrids was officially issued by the Bureau of Animal and Plant Health Inspection and Quarantine (BAPHIQ) in Taiwan in order to produce healthy and high quality seedlings without CymMV and ORSV infection (Chang et al. 2003). A similar certification programme for Phalaenopsis spp. is being developed. One of the detection methods frequently used in the certification programme is ELISA. The detection specificity and sensitivity of ELISA depend on the property of the antibodies. The commercial antibodies and laboratory made antisera prepared by purified virions of CymMV or ORSV have been used for field surveys of virus infection (Zettler et al. 1990; Wong et al. 1994; Ryu et al. 1995; Elliott et al. 1996). However, some orchid species produced non-specific reactions with these types of antisera due to them reacting with plant-derived contaminants (Elliott et al. 1996).

To avoid the potential problem of using antibodies produced by virion preparations, we chose bacterially expressed recombinant viral CPs as antigens. The CPs of CymMV and ORSV are ideal targets for virus detection because of their high sequence homologies among different isolates (Ajjikuttira et al. 2002). Therefore, the CP genes of CymMV and ORSV were cloned, expressed and used for antisera production. When compared with the CP genes of other CymMV isolates, our clone showed $88-97 \%$ identity at the nucleic acid level and 94-98\% identity at the amino acid level. The nucleic acid and amino acid sequences of our cloned ORSV CP gene resulted in 97-100\% and $96-100 \%$ identities, respectively, with other ORSV isolates (data not shown). Our sequence analysis results consistent with previous reports indicated that $\mathrm{CP}$ sequences of CymMV and ORSV are highly conserved (Ajjikuttira et al. 2002). Two antisera, HM-Cy and HM-OR, were produced from our recombinant CymMV and ORSV CPs, respectively. Based on immunoblot assays, both antisera were shown to possess high specificity without any cross-reaction with healthy orchids or each unrelated virus, whether in plant samples or purified virion 
preparations. In addition, both antisera displayed similar sensitivity to commercial antibodies in the IELISA test. In HM-Cy, it revealed a higher $\mathrm{S} / \mathrm{H}$ ratio than the commercial antibody (Fig. 4a; Table 1), and therefore it is easy to distinguish a diseased plant from a healthy one by HM-Cy. The lower background of HM-OR in the I-ELISA test due to fewer non-specific reactions with healthy plant antigens is helpful to identify the virus-infected samples (Fig. 4b; Table 1). Consequently, HM-Cy and HM-OR are efficient and accurate in the determination of positive and negative results in the ELISA test. These results demonstrated the advantages of using recombinant $\mathrm{CP}$ as an antigen for antiserum production, as previously reported (Kim et al. 1998; Li et al. 1998; Cerovska et al. 2002; Hélias et al. 2003; Abou-Jawdah et al. 2004).

Although there were several reports of CymMV and ORSV surveys in different countries (Wisler et al. 1979; Zettler et al. 1990; Hu et al. 1993; Wong et al. 1994; Ryu et al. 1995; Grisoni et al. 2004; Khentry et al. 2006), no related information is available in Taiwan. HM-Cy and HM-OR were then used to investigate the infection rate of these two viruses in cultivated Oncidium and Phalaenopsis spp. In the six commercial farms located in different parts of Taiwan, the overall infection rate for these two orchid viruses was $28 \%$ (Table 2). Detection results showed a higher incidence of CymMV (26.6\% in total) than ORSV (6.6\% in total), similar to most of the survey results except those in Korea, where ORSV was more prevalent than CymMV (Ryu et al. 1995). Interestingly, $80 \%$ of ORSV occurred with CymMV in the same plant but only $20 \%$ of CymMV coexisted with ORSV (Table 2). Further studies are necessary to elucidate the mixed infection phenomenon. Routine indexing of orchid seedlings is an effective way of managing virus diseases of orchids as indicated by farm VI; this had the lowest infection rate of CymMV and ORSV. This result provided supporting evidence for BAPHIQ to execute the certification scheme of orchids in Taiwan.

This study provided an alternative way of antiserum production for important orchid viruses, CymMV and ORSV. HM-Cy and HM-OR, antisera raised against recombinant viral $\mathrm{CPs}$, possessed high specificity and sensitivity similar to commercial antibodies. Moreover, their high $\mathrm{S} / \mathrm{H}$ ratio and low background value in I-ELISA tests provided a good reference in routine detection process. Accordingly, our antisera of CymMV and ORSV produced from recombinant $\mathrm{CPs}$ are suitable for the certification programmes of Phalaenopsis and Oncidium orchids in Taiwan due to their low cost and high specificity.

Acknowledgements We thank Mr. Heng Chang and Ms. Wen-Chi Hu for helping collection of orchid samples.

\section{References}

Abou-Jawdah, Y., Sobh, H., Cordahi, N., Kawtharani, H., Nemer, G., Maxwell, D. P., et al. (2004). Immunodiagnosis of Prune dwarf virus using antiserum produced to its recombinant coat protein. Journal of Virological Methods, 121, 31-38.

Ajjikuttira, P. A., Lim-Ho, C. L., Woon, M. H., Ryu, K. H., Chang, C. A., Loh, C. S., et al. (2002). Genetic variability in the coat protein genes of two orchid viruses: Cymbidium mosaic virus and Odontoglossum ringspot virus. Archives of Virology, 147, 1943-1954.

Arunasalam, G., \& Pearson, M. N. (1989). ELISA detection of Odontoglossum ringspot virus in mature plants and protocorms of Cymbidium orchids: potential solutions to problems of sample preparation time and low virus concentration. Journal of Phytopathology, 126, 160-166.

Barry, K., Hu, J. S., Kuehnle, A. R., \& Sughii, N. (1996). Sequence analysis and detection using immunocapturePCR of Cymbidium mosaic virus and Odontoglossum ringspot virus in Hawaiian orchids. Journal of Phytopathology, 144, 179-186.

Cerovska, N., Moravec, T., \& Veleminsky, J. (2002). Polyclonal antibodies to a recombinant coat protein of Potato virus A. Acta Virology, 46, 147-151.

Chang, C. A., Lee, H. H., Chen, C. C., Lin, M. J., \& Wang, C. P. (2003). Phytosanitary certification program of oncidium seedlings and its future prospect to the development of ornamental industry in Taiwan. Plant Pathology Bulletin, $12,141-148$

Chapman, S. N. (1998). Tobamovirus isolation and RNA extraction. In G. D. Foster \& S. C. Taylor (Eds.), Plant virology protocols (pp. 123-129). New Jersey: Humana.

Elliott, M. S., Zettler, F. W., Zimmerman, M. T., Barnett, O. W., Jr., \& LeGrande, M. D. (1996). Problems with interpretation of serological assays in a virus survey of orchid species from Puerto Rico, Ecuador, and Florida. Plant Disease, 80, 1160-1164.

Eun, A. J.-C., Huang, L., Chew, F.-T., Li, S. F.-Y., \& Wong, S. M. (2002). Detection of two orchid viruses using quartz crystal microbalance (QCM) immunosensors. Journal of Virological Methods, 99, 71-79.

Eun, A. J.-C., Seoh, M.-L., \& Wong, S.-M. (2000). Simultaneous quantitation of two orchid viruses by the TaqManÒ real-time RT-PCR. Journal of Virological Methods, 87, $151-160$.

Eun, A. J.-C., \& Wong, S.-M. (1999). Detection of Cymbidium mosaic potexvirus and Odontoglossum ringspot tobamovirus using immuno-capillary zone electrophoresis. Phytopathology, 89, 522-528. 
Eun, A. J.-C., \& Wong, S.-M. (2000). Molecular beacons: a new approach to plant virus detection. Phytopathology, 90, 269-275.

Grisoni, M., Davidson, F., Hyrondelle, C., Farreyrol, K., Caruana, M. L., \& Pearson, M. (2004). Nature, incidence, and symptomatoloogy of viruses infecting Vanilla tahitensis in French Polynesia. Plant Disease, 88, 119-124.

Hélias, V., Jacquot, E., Guillet, M., Le Hingrat, Y., \& GiblotDucray, D. (2003). Production of recombinant Potato mop-top virus coat protein in Escherichia coli and generation of antisera recognising native virus protein. Journal of Virological Methods, 110, 91-97.

Hu, J. S., Ferreira, S., Wang, M., \& Xu, M. Q. (1993). Detection of Cymbidium mosaic virus, Odontoglossum ringspot virus, Tomato spotted wilt virus, and potyviruses infecting orchids in Hawaii. Plant Disease, 77, 464-468.

Hu, W.-W., \& Wong, S.-M. (1998). The use of DIGlabelled cRNA probes for the detection of Cymbidium mosaic potexvirus (CymMV) and Odontoglossum ringspot tobamovirus (ORSV) in orchids. Journal of Virological Methods, 70, 193-199.

Hull, R. (2002). Matthews ' plant virology (4th ed.). San Diego: Academic.

Khentry, Y., Paradornuwat, A., Tantiwiwat, S., Phansiri, S., \& Thaveechai, N. (2006). Incidence of Cymbidium mosaic virus and Odontoglossum ringspot virus in Dendrobium spp. in Thailand. Crop Protection, 25, 926-932.

Kim, J. D., Koo, Y. B., \& Chang, M. U. (1998). Genome characterization of a Korean isolate of Cymbidium mosaic virus. Molecular Cells, 8, 181-188.

Lee, S.-C., \& Chang, Y.-C. (2006). Multiplex RT-PCR detection of two orchid viruses with an internal control of plant nad5 mRNA. Plant Pathology Bulletin, 15, 187196.

Li, R. H., Zettler, F. W., Purcifull, D. E., \& Hiebert, E. (1998). The nucleotide sequence of the 3'-terminal region of Dasheen mosaic virus (Caladium isolate) and expression of its coat protein in Escherichia coli for antiserum production. Archives of Virology, 143, 2461-2469.

Lim, S. T., Wong, S. M., Yeong, C. Y., Lee, S. C., \& Goh, C. J. (1993). Rapid detection of Cymbidium mosaic virus by the polymerase chain reaction (PCR). Journal of Virological Methods, 41, 37-46.
Lin, N.-S., \& Chen, C.-C. (1991). Association of Bamboo mosaic virus (BoMV) and BoMV specific electron-dense crystalline bodies with chloroplasts. Phytopathology, 81, 1551-1555.

Ryu, K. H., \& Park, W. M. (1995). Rapid detection and identification of Odontoglossum ringspot virus by polymerase chain reaction amplification. FEMS Microbiology Letters, 133, 265-269.

Ryu, K. H., Park, W. M., Chung, S. Y., \& Yoon, K. E. (1995). Occurrence of Cymbidium mosaic virus and Odontoglossum ringspot virus in Korea. Plant Disease, 79, 321.

Sambrook, J., \& Russell, D. W. (2001). Molecular Cloning: A laboratory manual (3rd ed.). New York: Cold Spring Harbor Laboratory Press.

Seoh, M.-L., Wong, S.-M., \& Zhang, L. (1998). Simultaneous TD/RT-PCR detection of Cymbidium mosaic potexvirus and Odontoglossum ringspot tobamovirus with a single pair of primers. Journal of Virological Methods, 72, 197204.

Sherpa, A. R., Bag, T. K., Hallan, V., \& Zaidi, A. A. (2006). Detection of Odontoglossum ringspot virus in orchids from Sikkim, India. Australasian Plant Pathology, 35, 69-71.

Tan, S. W.-L., Wong, S.-M., \& Kini, R. M. (2000). Rapid simultaneous detection of two orchid viruses using LCand/or MALDI-mass spectrometry. Journal of Virological Methods, 85, 93-99.

Wisler, G. C., Zettler, F. W., \& Sheehan, T. J. (1979). Relative incidence of Cymbidium mosaic and Odontoglossum ringspot viruses in several genera of wild and cultivated orchids. Proceedings of the Florida State Horticultural Society, 92, 339-340.

Wong, S. M., \& Chng, C. G. (1993). Evaluation of sample processing methods in detecting Cymbidium mosaic virus in orchids using indirect ELISA. International Journal of Tropical Plant Diseases, 11, 139-145.

Wong, S. M., Chng, C. G., Lee, Y. H., Tan, K., \& Zettler, F. W. (1994). Incidence of Cymbidium mosaic and Odontoglossum ringspot viruses and their significance in orchid cultivation in Singapore. Crop Protection, 13, 235-239.

Zettler, F. W., Ko, N.-J., Wisler, G. C., Elliott, M. S., \& Wong, S.-M. (1990). Viruses of orchids and their control. Plant Disease, 74, 621-626. 